Uşak Üniversitesi Sosyal Bilimler Dergisi

$2015,8 / 1$

\title{
Kadına Yönelik Cinsiyetçi Söylemin İnternet Haber Portallarında Yer Alma Biçimleri
}

\section{Zuhal AKMEŞE \\ Kemal DENIZ**}

"Bütün dünya bir sahnedir ve bütün erkekler ve kadınlar yalnızca birer oyuncu: Çıkışları ve girişleri vardır hepsinin; ve bir insan hayatı boyunca birçok rolde oynar"

William Sheakspeare

\section{Özet}

Günümüzde kadına dair cinsiyetçi söylemler bütün medya mecralarında yer almaktadır. Kadını belirli kalıpyargılar içerisine sıkıştıran ve kadına belirli roller yükleyen bu söylem kitle iletişim araçları aracılığıyla meşrulaştııılmaktadır. Yeni teknolojilerin haber kaynaklarını çoğalttığı ve gazete, radyo-televizyon gibi geleneksel kaynaklar dışında kurumsal internet haber sitelerinin de günlük yaşama girdiği bir gerçektir. Ancak, bu yeni kaynakların da geleneksel medyanın söylemini takip ettiği ve cinsiyetçi bakış açısını devam ettirdiği söylenebilir. Ülkemizde toplumsal cinsiyet açısından kadına, erkeğe bağımlı ve kırılgan bir rol verilmesi ve bunun erkeğin egemenliğini pekiştiren yapının devamı olduğu düşünülebilir. Bu çalışmada, internet haber portallarında kadınların yer alma biçimleri incelenmiştir. $\mathrm{Bu}$ amaçla en çok izlenen haber portalının, kadınlarla ilgili yapılan haberlerinin konu, dil ve söylem incelemesi yapılmıştır.

Anahtar Kelimeler: Cinsiyetçi Söylem, Kadın, Temsil, Haber Portalları, Kadın Haberleri.

\footnotetext{
* Arş. Gör., İstanbul Üniversitesi İletişim Fakültesi

** Arş. Gör., İstanbul Üniversitesi İletişim Fakültesi
} 


\title{
Gendered Discourse against Women and the Ways It Takes Place in an Internet News Portal
}

\begin{abstract}
When evaluating the position in the social structure of women in Turkey, it can be considered that, in terms of gender, women are given a role that they are vulnerable and dependent on men and this is the continuation of the structure that reinforces male dominance. Nowadays, gendered discourses about women located in various mediums in a way that continues this structure. This discourse in which women are forced through certain stereotypes and that loads them into certain roles, are legitimized by the mass media and various mediums. And one of these mediums is online news portal. In this study, it is aimed to examine how the news about women take place in an online news portal. For this purpose, because the most watched news portal between the date of the examination carried out was http://www.hurriyet.com.tr, news included women in this online news portal is evaluated in fifteen day period in terms of issues, language and discourse; and the ways how news about women take part in this medium has been studied in the context of gender.

Key Words: Gender Discourse, Gender, Woman, Representation, News Portals, Woman News.

\section{Giriş}

İletişim tarihine bakıldığında iletişimin bir disiplin olma yolundaki çabalarının tarihle birlikte anıldığ görülmektedir. İnsan ortaya çıktığı ilk andan itibaren duygu, düşünce ve ihtiyaçlarını aktarabilmek, yaşamını sürdürmek için farklı yöntem ve teknikler kullanarak çevresiyle iletişim kurma çabalarını başlatmıştır. Kadınlık ve erkeklik kavramlarına bakıldığında bu kavramların da insanlık tarihiyle birlikte ortaya çıtığı görülmektedir. İlk insanın ortaya çıkmasıyla birlikte kadın ve erkek toplumsal alanda var olmuştur. Toplumsal alanda var olan kadın ve erkeğe dair rol modellerin oluşmasını sağlayan bir takım kültürel ve toplumsal değerler vardır. Bu değerler tarihsel süreç içerisinde şekillenmektedir.

Tarihsel süreç içerisinde kadın ve erkeğin gelişimi incelendiğinde, bu kavramların toplumsal alanda yer almasiyla birlikte toplumsal örgütlenmenin tarzının da cinsiyet farklılıklarına dair rol kalıplarının belirleyici olmasında etkili olduğu görülmektedir. Özellikle batıda 19. yüzyıl Sanayi Devrimi'nden sonra kadınların büyük ölçüde özel alana hapsedildiği buna karşılık kamusal alanın da erkeğe atfedildiği ve erkeğe ait bir alana
\end{abstract}


dönüştürüldüğü görülmektedir. Toplumsal arenadaki bu özel-kamusal alan ayırımı ve kamusal alanın tamamiyle erkeğe bırakılması karşılığında kadının özel alana hapsedilmesi kültürel değerlerle desteklenerek kadın ve erkeğe dair toplumsal cinsiyet rollerinin şekillenmesine yol açmış, kadın tamamiyle ikinci plana itilmiştir. Bu durum özünde toplumda yaratılan ataerkil bakış açısının ve bu bakış açısıyla üretilen değerler ile bu değerlerle kadını şekillendiren toplumsal cinsiyet rollerinin ürünü olarak değerlendirilebilir.

Kitle iletişim araçlarında, kadının temsiliyet biçimi medya çalışmaları içerisinde temel alanlardan birini oluşturmaktadır. Kitle iletişim araçları genelinde kadın, birçok boyutuyla medyada yer alma biçimleriyle araştrımaların konusunu oluşturmaktadır. $\mathrm{Bu}$ araştırmalar kadının televizyon programları, diziler, filmler, haberler, reklamlar gibi çeşitli medya mecralarında cinsel obje olarak kullanılıp kullanılmadığı, söz konusu haber ya da programda nesne olarak mı özne olarak mı kullanıldığı ya da kadının bu mecralarda toplumsal cinsiyet algısının oluşturduğu stereotipleştirilmiş görünümleri incelenir. Çalışmaların çoğunda dikkat çeken nokta, kadınların hangi medya mecrasında olursa olsun eril bakış açısı altında ele alındığı, nesne, cinsel obje ve toplumda yer alan stereotipler içinde ele alındığına dikkat çekilmektedir.

$\mathrm{Bu}$ çalışmanın temel sorunsalı, yeni medya olarak tanımlanan internet mecrasındaki haber portallarında kadının yer alış biçimlerini incelemek ve kadının tanımlanmasına yönelik bir analiz yaparak en çok tıklanan haber sitesinde yapılan kadın haberleri bağlamında kadının temsiline dair verilere ulaşmaktır.

Geleneksel medyada mevcut ataerkil düşünce yapısının ve eril bakış açısının ve bu bakışla kadına yaklaşımın yeni medyada var olup olmadığ incelenmiş bu mevcut bakış açısının varlığı durumunda yeni medyada nasıl yer aldığı yapılan analizler sonucunda değerlendirilmiştir.

\section{Geleneksel Medya - Yeni Medya}

Medya, günümüzde en çok kullanılan kavramlardan biridir. Kelime latincede araç, ortam anlamına gelen medium kelimesinin çoğul halidir. Medya; gazete, dergi, radyo, televizyon, internet vb. kitle iletişim araçlarının bütününü kapsayan genel bir terim olarak kullanılmaktadır (http://www.medyahukuku.org/makale/medya-nedir/). Bu bağlamda medyayı kitle iletişim araçlarının bütününü ve bu araçlar aracıllğıyla gerçekleşen iletişim ve iletişim ortamlarını tanımlamak için kullanıldığını ifade etmek mümkündür. Kitle iletişim araçlarının haber alma ihityacıyla ortaya çıtığı gerçeğinden hareketle medyanın yeni teknolojilerle paralel 
olarak sürekli geliştiği, format değiştirdiği ve etki alanını genişlettiği görülmektedir.

Gazete, dergi, radyo ve televizyonun ortaya çıkışı süreç içerisinde haberin yanında ses ve görüntü, ardından hareketli ve sesli görüntülerin kullanımı hedef kitle üzerindeki etkiyi daha da arttırmıştır. Teknolojilerin sürekli gelişmesi, medyanın anlam ve içeriğinde de birtakım değişiklikleri beraberinde getirmiştir. Günümüzde medya sadece bir haber alma/verme aracı olmaktan çıkmış, kitlelerin hayatına yön veren toplumsal değerleri üreten, içerisinde bilgi alışverişi, eğlence, yaşam tarzı, iletişim, ekonomi, politik ve hayatla ilgili her alanı kapsayan, biçimlendiren ve yeniden üreten bir alan haline gelmiştir. Günümüzde gelişen yeni teknolojiler kişilerarası bilgi aktarımının şekli ve boyutlarında ciddi değişimler meydana getirmiştir. Bu bağlamda sosyoloji, hukuk, felsefe, ekonomi, tarih, psikoloji, siyaset bilimi ve daha birçok disiplinin kesişme alanında yer aldığı için disiplinlerarası bir alan olarak kabul edilen iletişim alanında da iletişim teknolojilerinin gelişmesiyle hem nicel hem de nitel anlamda köklü değişimler yaşanmıştır (Uluç, 2003: 11).

Medyanın bu özellikleri dışında bir sektör olarak da çok ciddi bir alan olduğunu ifade etmek mümkündür. Medya üretimleri, televizyon kanalları, dergiler, gazeteler, internet portalları kitleler üzerinde yarattıkları etki ve yönlendirme gücü sayesinde milyar dolarlık yatırımların olduğu alanlar haline gelmiştir. Bu anlamda da günümüzde medya çok ciddi yatırımların yapıldığı ve sahipliğinin son derece stratejik olduğu alanlardan birini oluşturmaktadır. Bu sektör küresel bazlı dev şirket ortaklıklarından yerel kaynaklı kuruluşlara kadar ticari her türlü kitle iletişim faaliyetini bünyesinde barındırmaktadır.

Jan van Dijk (2004); sanal uzamda gerçekleşen edimlerin gündelik yaşamda geleneksel medyanın kapladığı yeri ve zamanı almakta ve yaşamın akışının doğal bir parçası haline gelmekte olduğunu belirterek, yeni medyanın kavramsallaştırımıyla, geleneksel medyadan (gazete, radyo, televizyon, sinema) farklı olarak, dijital kodlama sistemine temellenen, iletişim sürecinin aktörleri arasında eşanlı ve çok yoğun kapasitede, yüksek hızda karşılıklı ve çok katmanlı etkileşimin gerçekleştiği multimedya biçimselliğine sahip iletişim araçlarının kastedilmekte (Binark, 2007: 5) olduğunu söylemektedir.

Yeni medya kavramına baktı̆̆ımızda, yeni medyanın internet teknolojisiyle birlikte anıldğı görülmektedir. İnternetin soyal hayatta kullanılmasıyla birlikte interaktif etkileşimin olanaklı olduğu, zaman ve mekân kavramının ortadan kalktığı, bireylerin internet aracilığıyla sosyal ağlar üzerinden dünyanın bir ucundan öteki ucuna ileti, görüntülü-sesli 
videolar vb. mesajları gönderme olanağı sunan bir plaformla karşılaşmaktayız. Yeni medya ile kitle izleyicisi aynı zamanda bireysel kullanıcı olarak varlık gösterebilme olanağına sahip konuma gelmiştir.

Teknik olarak yeni medyaya baktığımızda; ses, video, veri, grafik ve multimedya uygulamalarını tümü sayısal bilgileri işlemek için tasarlanmışken daha sonra bu ses, video ve veri hizmetleri işlenebilir, depolanabilir ve bilgisayarlar ile telekomünikasyon araçları vasıtasıyla iletişim kurulabilir. Bu farklı uygulamaların altında yatan sayısal yapısı, üretilenlerin kablo, uydu, mikrodalga ve diğer telekomünikasyon sistemlerini kapsayan çeşitli kanallarla dağıtılmasını sağlar. Bu bağlamda yeni medya sayısal medyadır. Bilgi ve iletişim teknolojilerine dayanır (Green, 2010: 5). Bütün bu gelişmeler beraberinde medya da değişim ve dönüşümü getirmiştir. Son yıllarda medya niceliksel ve teknolojik olarak ve daha geniş kamusal katılım bağlamında benzeri görülmememiş oranda değişiklikler geçirmiştir. Yeni medya formları ortaya çıkmış, gazete ve radyo, televizyon ve internet aracılığıyla birleşmiştir. İletim hızı artmış ve çok fazla okuyucu/izleyici aktif veya pasif olarak katılım sağlamıştır (Aitchison ve Lewis, 2003: 1). Bu katılım internet teknolojilerinin bireysel kullanıcıya sağladığı olanaklar doğrultusunda sosyal ağlar üzerinden gerçekleşmektedir.

Kitle iletişim araçlarının gelişimi ve yeni teknolojilerin bu mecrada kullanımı geleneksel ve yeni medya karşılaştırması gibi türlü karşılaştırmaları ve bu alanla ilgili bir takım akademik çalışmaların yapılmasını gündeme getirmiştir. Alanla ilgili çalışmalar değerlendirildiğinde geleneksel/yeni medya karşılaştırmasının genelde teknik anlamda meydana gelen değişimleri, yeni medyanın bilgiye ulaşma, iletişim kurma anlamındaki üstünlüklerinden ötürü getirdiği avantajlara yer verildiği görülmektedir. Genel olarak internet teknolojisinin özellikleri ve sağladığ $ı$ avantajlar ele alındığında internetin özelliklerini kısaca şu şekilde ifade etmek mümkündür (Aziz, 2010: 129-130) :

- İnternet iletişim teknolojilerinin bir koleksiyonudur.

- Yazılı iletişim araçları, telefon, iletişim uyduları, yazılı, sesli ve görüntülü kitle iletişim araçları, kitap, fotoğraf, bilgi kaydetme/ depolama teknikleri gibi tüm iletişim teknolojilerini kullanır.

- İnternet tüm medyanın vermiş olduğu hizmetleri yerine getirir.

- İnternet ticari firsatlar yaratır.

- İnternet etkileşimli (interaktif) olarak iletişim sağlar.

Bu bağlamda yeni medya olarak kullanılan internet teknolojisinin bütün kitle iletişim araçlarının fonksiyonlarını bir arada kullanabildiği ve 
bireyin bütün kitle iletişim araçlarının toplamına internet aracıyla ulaşabildiği bir mecra yaratmıştır.

Kitle iletişim araçları aracılığıyla dolaşıma giren haber tanımını ele aldığımızda; herhangi bir zamanda geçen olay, fikir ya da sorunun özeti (Tokgöz, 2013: 244) olarak tanımlamak mümkündür. Medya mecrasında üretilen haber ve söylemini tek bir açıdan karakterize etmek değerlendirmek sağlıklı bir sonuca ulaşmamızı engeller. Haber söylemi sadece onun çeşitli yapılarına göre karakterize edilmemelidir. Ayrıca karmaşık bir iletşim sürecinin bir parçası olduğu da dikkate alınmalıdır. Süreçler ve yapılar entegredirler ve karşılıklı olarak haber söyleminin özelliklerine bağlıdırlar. Haber üretim süreci kaynak metnin yapılarının bir fonksiyonudur ama ayrıca gazeteci tarafından yazlacak haber metninin altında yatan yapısal tasarılara da bağlıdır. Benzer şekilde, okuma, anlama ve inanç oluşumu ve kullanım süreçleri okuyucu tarafından haber metinlerinde tahsis edilen yapılarla koşullanmaktadır (Van Dijk, 1988: 95). Medya içeriği ele alındığında haber söylemi ve içeriğin hangi perspektiften ve hangi bakış açısıyla sunulduğu önem taşımaktadır.

Kitle iletişim araçları ilk ortaya çıktı̆̆ı andan günümüze kadar toplum üzerinde etkili olmuştur. Toplumsal değerler, yaşam tarzı, toplumsal yaşamın tasarımı ve inşası için bir araç olarak işlev görmüştür. Geleneksel ve yeni medya arasında bir değerlendirme yapıldığında yeni iletişim teknolojilerinin kitlelere ulaşma, kitleleri etkileme ve kitlelerin bireysel olarak sürece dahil olmasına olanak tanıyan teknolojileri bünyesinde barındırmasına rağmen kültürel değer, toplumsal yapıya dair bakış açısının haber metinleri ve medya üretimlerinde içerik ve perspektif olarak bir farklılık göstermediği gözlenmektedir. Kadının medya da temsiline dair çalışmalara bakıldığında, kadının toplumsal yapı ve kültürel değerler içerisindeki konumunun hem geleneksel medya da hemde yeni medyada korunduğu dikkat çekmektedir. Toplumsallaşma sürecinde etkin rol oynayan aile, okul, medya ve benzeri kuruluşlar farklı oran ve biçimlerde toplumsal cinsiyet ilişkilerinin şekillenmesinde bir rol oynamaktadır. Bu kurumlar aracılığıyla şekillenen toplumsal cinsiyet ilişkileri erkek egemen söylemin değerleri doğrultusunda oluşturulduğu için bu değerlerin sürekli yeniden üretilmesine katkı sağlamakta ve bu değerleri meşrulaştırmaktadır. Bu noktada medyanın yani iletişim araçlarının etkin rol oynadığını söylemekolanaklıdır. Bu durum toplumsal kontrolün sağlanmasında ve eril bakış açısının meşrulaştırılarak devamlılı̆ı̆ı sağlanmasına katkıda bulunmaktadır. Gerek geleneksel gerekse yeni medya da yer alan üretimlerde kadın imgesinin 3.sayfa (ölüm, tecavüz, suçlu, mağdur, şiddet kaynağı, şiddete maruz kalan, cinsel obje vs.) 
ve son sayfa (güzel, seksi, cezbedici, arzu nesnesi) arasında konumlandırıldığı görülmektedir. Medya kadınlar ve dişilik hakkında sırasıyla streotipik, ataerkil ve egemen değerleri aktaran temel araçlar olarak algilanır. Bunlar toplumsal kontrol düzenekleri olarak hizmet ederler. (Van Zoonen, 1996: 40). Bu bağlamda yeni iletişim teknolojilerinin mecra olarak çok farklı ve yenilik getirmesine rağmen içerik olarak geleneksel medyanın devamı olduğunu söylemek mümkündür.

Toplumsal Cinsiyet Kavramı ve Medya İlişkisi: Kadının Haberlerde Yer Alma Biçimleri

Medyanın kitleler üzerindeki biçimlendirici gücü son derece etkindir. Medya kişilerin psikolojik yapısına derinlemesine nüfuz ederek zihinlerine yayılmakta böylece ne söylemeleri ve ne yapmaları gerektiğini öğretmektedir. $\mathrm{Bu}$ bağlamda medya çok güçlü bir ikna, tanıtım ve propaganda kaynağıdır (Laughey, 2010: 42). Medya toplumsal cinsiyetin yeniden oluşturulmasında da etkin bir rol oynamakta, toplumsal cinsiyet tasarımı ve inşasında, cinsiyet imgelerinin kurulmasında etkilidir. Medyada yerleşik olan ve yeniden üretilen cinsiyet kalıplarının da toplumda yer alan cinsiyete ait öğrenilmiş kalıp yargılar paralelinde olduğu görülmektedir.

Cinsiyet (sex) ve toplumsal cinsiyet (gender) üzerinde durmak, biyolojik ve toplumsal anlamda bu kavramların hangi noktada ayrıştığını ortaya koymak önemlidir. Cinsiyet, kadın veya erkek olmanın biyolojik yönünü ifade eden bir terimdir. Bireyin biyolojik cinsiyeti bağlamında demografik bir kategori olarak beliren cinsiyet terimi olarak nüfus cüzdanında yer alan cinsiyet örnek olarak verilebilir. Toplumsal cinsiyet terimi ise, toplum ya da kültürün kadınlık ve erkekliğe dair yüklediği anlam ve beklentileri ifade etmekte, kültürel bir yapıya karşılık gelmekte ve genellikle bireyin biyolojik yapısıyla ilişkili olan psikolojik özelliklerini de içinde barındırmaktadır. Bu bağlamda bireyleri kadınsı (feminen) ya da erkeksi (maskülen) şeklinde karakterize eden toplumsal cinsiyet, psikososyal özelliklerdir. Kültürün kadından ve erkekten bekledikleri (toplumsal cinsiyet), kadının ve erkeğin fiziksel bedenlerine (cinsiyet) ilişkin gözlemlerden tamamen ayrı olmadığından cinsiyet ve toplumsal cinsiyeti birbirinden bütünüyle ayırmak mümkün değildir. Böyle değerlendirildiğinde, toplumsal cinsiyetin kültürel yapılanmalarının biyolojik cinsiyeti de içerdiği görülmektedir (Bayhan, 2012: 148). Toplumsal cinsiyet ve medya ilişkisi incelendiğinde, medyanın cinsiyetin tasarım ve inşası için etkili bir mecra olarak kullanıldığı, toplumda cinsiyet düzenini yapılandırmada da yardımcı bir rol üstlendiği (İmançer, 2006) görülmektedir. 
Toplumsal cinsiyet rolleri ve bu roller bağlamında erkeğin kadından üstün gösterilmesi, erkek kimliğine olumlu anlamlar yüklenirken, kadının daha pasif ve erkeğe bağımlı bir nesne olarak temsil edilmesi, biyolojik bir farklılığın değil, toplumsal etkileşimle inşa edilen, onaylanan ve meşrulaştırılan bir yapının ürünüdür. Erkek üstünlügüüü temele alarak oluşturulan bu yapı gündelik uygulamalarda hayatın bir parçası haline gelmekte, hem toplumsal hemde kurumsal düzlemde cinsiyete özgü yapılar ortaya çıkmakta ve hayatın her alanında etkileri görülmektedir. Aileden devlet kurumlarına varıncaya dek bu bu roller iki farklı (kadın/erkek) cinsel kimliğe sahip bireylerin yaşantısını yönlendirmede etkili olmaktadır. Medyanın oğlan cocuğu ve erkekleri, aktif, maceraperest, güçlü, cinsel olarak daha girişken ve insan ilişkilerinde büyük oranda karışmayan şekilde temsil etmesine karşın, kız çocuğu ve kadınlar genç, ince, güzel, pasif, bağımlı, yetersiz olarak temsil edilir (Wood, 2009: 259). Bunlar baskın cinsiyetçi söylemlerdir ve bu söylemlerin medya mecrasında yoğun kullanımı görülmektedir. Medya kalıp yargıları kadınları cinsel nesneler, itaatkar, daha az bilgi sahibi, ev temizliği ve çamaşır benzeri ev işlerinin işçileri olan ev kadınları olarak öngörülmüş roller ile ortaya koyar. Bu öngörülen rollere ek olarak medya fizkisel güzellikle değerlendirilen iletiler gönderir. Bu iletiler çeşitli medya formlarına da yayılmıştır. İnternet de toplumsal cinsiyet kalıp yargılarının sosyo-kültürel bağlamda aktarılmasındaki en son mecra olarak karşımıza çıkar (Pacheco ve Hurtado, 2002: 703). Medya potansiyel olarak kendimizi kadın ya da erkek olarak anlamamızı üç şekilde çarpıtır. Birincisi medya kadınlar ve erkeklerin gerçek olmayan ideallerini sürekli tekrarlar. İkincisi medya erkeklerin ve özellikle de kadınların vücutlarını normal fiziksel özellikleri ve fonksiyonları anormal, çirkin, düzeltilmesi gerekli olarak algılamamızı sağlayarak hastalıklıymış gibi gösterir. Üçüncüsü ise medya kadına şiddetin kanıksanmasına katkıda bulunur (Wood, 2009: 275). Medya üretimlerinin oluşturduğu bu imgeler durumun olağanlaştırılmasına hizmet etmektedir. $\mathrm{Bu}$ noktada cinsiyet ayrımcı ideolojilerin kadınlar ve erkekler arasındaki günlük etkileşimlerin neredeyse tüm biçimlerini yönlendirdiğini (Van Dijk, 2003: 44) söylemek olanaklıdır.

Söylem ve cinsiyet üzerine çalışma dilbilim, antropoloji, sözlü iletişim, sosyal psikoloji, eğitim, edebiyat ve diğer alanlardaki bilim insanları tarafından paylaşılan disiplinler arası bir çabadır. Birçok araştırmacı, öncelikle dil kullanımının toplumsal cinsiyetle ilgili kalıplarının belgelenmesiyle ilgilenmiştir, ancak alan aynı zamanda dil çalışmalarını, cinsiyet ilişkilerinin toplumsal ve siyasal yönlerini görmeyi sağlayan bir objektif olarak değerlendiren birçok uzamanı da içinde barındırmaktadır. Bu 
iki bakış açısı arasındaki gerginlikler ilk araştırmada ortaya çıkmış ve bugün devam etmektedir. Araştırmaların ortaya çıktığı bakış açıları ne olursa olsun, toplumsal cinsiyet ve söylem çalışması sadece eril/dişil söylemin tanımlayıcı bir açıklamasını sağlamaz, aynı zamanda dilin nasıl kişisel, sosyal ve kültürel anlamlar ve kimlikler yaratmada sembolik bir kaynak işlevi gördüğünü de açığa çıkarır (Kendall ve Tannen, 2001: 548). Toplumsal cinsiyet ve dil ilişkisi ile ilgili çalışmasında Fransız feminist Helene Cixous dildeki yapı üzerinde durmuş, kültürün dilin kendisi olduğunu, insanın doğar doğmaz içinde bulunduğu dil aracıllğıyla kendini bireye empoze ettiğini ifade etmiştir. Dilin yapısının ikili karşıt terimler üzerine geliştiği, bu karşıtlı̆̆ın bir hiyerarşiyi de beraberinde getirdiğini ve bu hiyerarşik yapılanmanın tümünün yaşantımızda kadın/erkek ilişkilerine dayandığını ifade eden Cixous; güneş erkek, kadın ay, aktif erkek, pasif kadın gibi ikileme dayanan, kadın ve erkekle özdeş tutulan kavramların pozitif olarak kurgulandığını, kadının böylece erkek dünyasında onun terimleriyle bir anlam kazandığını; ya görmezlikten gelindiği ya da "erkeğin diğeri" olarak kabul edildiğine vurgu yapmıştır (Çağlar, 2003). Günlük yaşantımızda kullandığımız dil incelendiğinde ailede ve toplumda konuşulan dilin yakın ilişki içinde olduğu görülmektedir. Kullanılan sözcükler ve cümle kurguları cinsiyete dayalı ayrımcılığı dil aracılığıyla yeniden üretmektedir (Alankuş, 2000 : 107). Örneğin bilim adamı, siyaset adamı, işadamı vb. kelimeler söz konusu etkinliğin, ya da alanın sadece erkeklere ait olduğunu vurgulayan terimler olarak karşımıza çıkarken, "doğrucu Davut, sözünün eri" vb. kelimeler ise dilin ideolojik bir nitelik taşıdığını göstermektedir (Tanrı̈ver, 2007: 167). Medyada kullanılan dil incelendiğinde, özellikle ana akım medya kuruluşlarında erkek egemen cinsiyetçi söylemin büyük ölçüde kullanıldığı görülmektedir.

\section{İnternet Haberlerinde Kadının Yer Alma Biçimleri}

Yeni medya olarak adlandırılan internet mecrasında günlük gazetelere web adresleri üzerinden ulaşmak mümkündür. Günlük gazeteler internet üzerinden kitlelere haber aktarımı yapmakta ve kitlelere bir takım bilgi akışı sunmaktadır. Bu çalışmanın temel sorunsalı yeni medya olarak tanımlanan internet mecrasında bilgi ve haber paylaşımı gerçekleştiren haber portallarında yer alan haberler üzerinden kadının medyada yer alış biçimlerine dair saptamalarda bulunmaktır. Amaç geleneksel medya da yer alan eril bakışın ve kadına dair cinsiyetçi söylemin internet mecrasında yer alıp almadığına dair bir değerlendirmede bulunmaktır. Bu mecradaki söylem biçimleri ve kadının medyada temsiliyet biçimi örnek haberler üzerinden değerlendirilmiştir. 


\section{Amaç ve Yöntem}

Çalışmanın amacı, internet haber portallarında yer alan haberlerde kadınnın temsiliyet biçimlerinin analizini yapmaktır. Bu bağlamda Alexa verilerine göre Türkiye'de en çok tıklanan haber portalı olan hurriyet.com.tr haber portalı incelenmiştir. 01.01.2014-15.01.2014 tarihleri arasında hurriyet.com.tr haber portalında yer alan ve doğrudan veya dolaylı olarak içerisinde kadın yer alan ilk sayfa haberlerinde kadının konumlanış biçimi, haberin konusu, haberin niteliği, haber kaynakları ve kadına atfedilen sıfatlar incelenmiştir.

\section{Bulgular}

15 günlük aralıkta yapılan analizler sonucunda toplam 77 haber dil, söylem ve içerik açısından değelendirilmiştir. Haber analizlerine bakıldığında, içerisinde kadın geçen haberlerin 42 'sinin basit haber, 16'sının karmaşık haber, 15'inin özel konulu haber, 4'ünün ise genel haber kategorisinde olduğu saptanmıştır. Kadının haberde yer alış biçimleri incelendiğinde 45 haberde mağdur, 6 haberde suçlu, suçlanan, 6 haberde çalışma alanında, 13 haberde ünlü bir kişi ile ilişkilendirilmiş (anne, sevgili, eş vs), 3 haberde protestocu-eylemci ve 9 haberde de farklı şekillerde yer aldığı saptanmıştır.

01.01.2014-15.01.2014 tarihleri arasında hurriyet.com.tr portalında ilk sayfada yer alan haberlerden içerisinde kadın yer alan toplam 77 haber incelenmiştir. Portalda yer alan haberlerin haber kaynaklarına baktığımızda; DHA (28) \%73, AA (7) \%18, CHA (1) \%2, BBC (2) \%5 oranında haber kaynağı olarak kullanıldığı görülmektedir.

Tablo 1: Yayınlanan kadın haberlerinin haber kaynaklar!

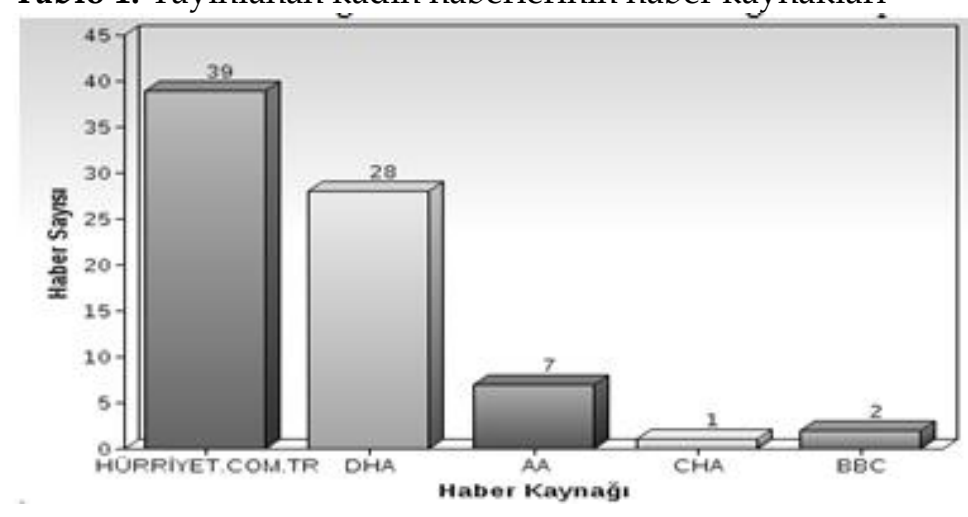


İncelenen haberler metinleri niteliklerine göre de ayrilmıştır. Niteliklerine göre haber metinleri şu kategorilerde değerlendirilmektedir:

“Genel Haberler: Konu olarak her zaman ortaya çıkan haberlerdir;

- Kısa kişi haberleri

- Konuşmalar, mülakatlar

- Toplantılar, törenler

Basit Haberler: Konulu haberlerdir.

- Ölüm, hastalık, cenaze haberleri

- Yangin, kaza, sel, deprem haberleri

- Mevsim, hava durumuyla ilgili haberler

Karmaşık Haberler: Haberlerin daha iyi oluşturulmasında gereklidir.

- Mahkeme, duruşma, dava

- Hükümet, politika

- İş, endüstri, tarım, çalışma yaşantısı

- Eğitim, araştırma, bilim, uzay, deniz

- Din, felsefe vb.

\section{Özel Konulu Haberler:}

- Sosyete-kadin

- Spor

- Edebiyat, güzel sanatlar (Kars, 2013: 183-4)."

Niteliklerine göre haberler analiz edildiğinde; toplam 77 haberden, 42 tanesinin (\%54) basit haber, 16 tanesinin (\%20) karmaşık haber, 15 tanesinin (\%19) özel konulu haber, 4 tanesinin (\%5) genel haber kategorisinde yer aldığı görülmektedir.

Tablo 2: Yayınlanan kadın haberlerinin niteliklerine göre dağılımı

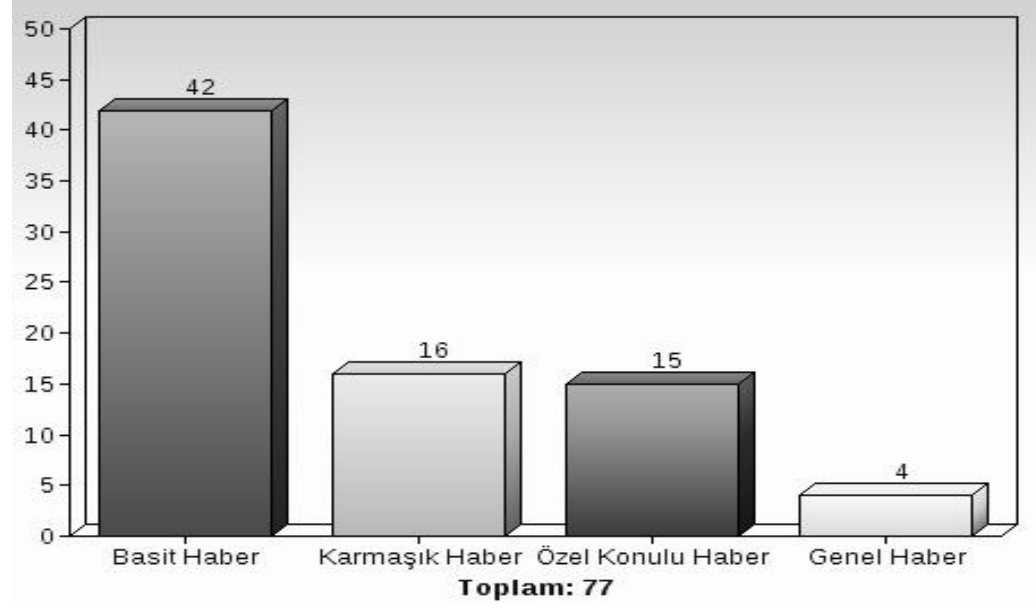


Kadının haberlerde temsil biçimlerine bakıldığında; kadının toplam 77 haberden $45^{\prime}$ inde (\%54) mağdur ya da kurban, 13'ünde (\%15) tanınmış kişi ya da yakını (ünlü akrabası, eşi, annesi, sevgilisi), 6'sında (\%7) çalışma alanı/ başarısını (çok minimal düzeyde), 6'sında (\%7) şüpheli-suçlu, 3'ünde (\%3) eylemci-protestocu ve 9 haberde (\%10) diğer şekillerde konumlandırıldığı görülmektedir.

Tablo 3: Kadının haberlerde konumlanış biçimi

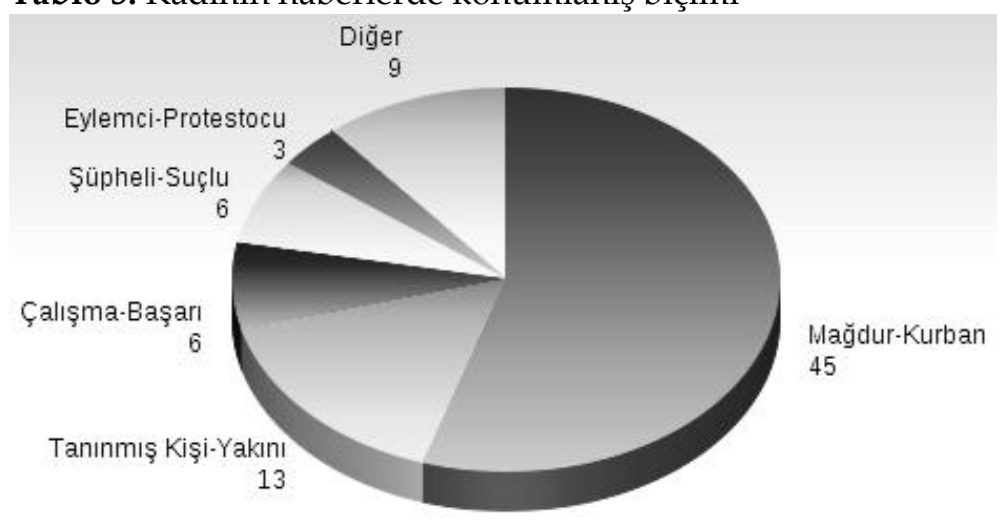

İncelemeye tabi tutulan haberlerde kadına atfedilen 301 sifat arasında; 97 (\%32.2) kadın, 56 (\%18.6) anne, 21 (\%6.9) eş, $6(\% 1,9)$ sevgili, 2 $(\% 0.6)$ gelin, $2(\% 0.6)$ kuma, $4(\% 1.3)$ hanım, $2(\% 0.6)$ bayan, $6(\% 1.9)$ prenses, $2(\% 0.6)$ gizli/yasak aşk, 1 (\%0.3) güzellik kraliçesi, 7 (\%2.2) first lady, 3 $(\% 0.9)$ kayın valide, $2(\% 0.6)$ anneanne, $1(\% 0.3)$ babaanne, $2(\% 0.6)$ abla, 1 (\%0.3) yabancı uyruklu kadın, 65 (\%21) kız, 7 (\%2.2) genç kız, $7(\% 2.2)$ kız çocuk, 4 (\%1.3) kız çetesi, 1 (\%0.3) hala, $1(\% 0.3)$ teyze, 1 (\%0.3) görümce olarak yer aldığı görülmektedir.

\section{Sonuç ve Değerlendirme}

$\mathrm{Bu}$ çalışmanın amacı yeni medya olarak tanımlanan internet mecrasında kadının konumlandırılışını incelemek, yeni medya ve geleneksel medya arasında kadının temsil biçimlerine dair bir takım değerlendirmelerde bulunmaktır. Bu amaçla internette yer alan haber portallarında kadının temsil biçimleri üzerine bir araştırma yapılmıştır. Bu araştırma "Alexa" verilerine göre Türkiye'de en çok tıklanan internet haber portalı olan "www.hurriyet.com.tr"nin 15 günlük haber analizlerinden oluşmaktadır. 
Bu bağlamda Alexa verilerine göre en çok tıklanan haber portalı www.hurriyet.com.tr'nin ilk sayfası 01.01.2014 - 15.01.2014 tarihleri arasında 15 günlük bir süre ile incelemiştir. Bu 15 günlük aralıkta haber portalının ilk sayfasında yer alan ve içerisinde doğrudan veya dolaylı olarak kadın geçen haberler analiz edildi. Bu analiz söz konusu 77 adet haberin dil, söylem, konu açısından değerlendirilmesinden oluşmaktadır. Bunun dışında haber portalında yer alan söz konusu haberlerin; haber kaynakları, haber metinlerinin türü de değerlendirilmeye alınmıştır. Yapılan araştırma sonucunda elde edilen veriler aşağıdaki gibidir;

- Kadınlar haberlerin \%54'ünde mağdur ya da kurban olarak yer almıştır.

- Kadınlar haberlerde özne olarak varlık göstermekten ziyade haberlerin \%15'inde tanınmış bir kişi veya o kişinin yakını olarak yer almıştır.

- Haberlerde yer alan kadın temsilleri genellikle mağdur, suçlu, şüpheli, eylemci, protestocu şeklinde yansitılmıştır.

- Kadınların iş hayatı, başarıları ve benzeri olumlu haberlere çok az ya da hiç yer verilmediği görülmüştür.

- Kadınlar için anne, eş, sevgili, gelin, kuma, bayan, prenses, yabancı uyruklu, hanım vb. sıfatların kullanıldığı görülmektedir. Kullanılan sıfatlara baktığımızda kadını yüceltici başarısını, kişiliğini olumlayıcı sıfatlara rastlanmazken, genellikle kadının başka bir kişi üzerinden tanımlanmasını sağlayan (anne, eş, sevgili, kayın valide vb) sıfatlar ile kadının fiziksel özellikleri ve cinselliğini (güzellik kraliçesi, prenses, cazibe, taş bebek vs.) ön plana çıaran sıfatların kullanıldığı görülmektedir.

- Haber içeriklerine ve kadının haberde konumlanışına bakıldığında, incelenen haberlerin çoğunda kadının ünlü yakını mağdur, ünlü kazazede, tacize uğrayan, kocası tarafından şiddete maruz kalan, futbolcu sevgilisiyle boy gösteren, çeşitli hastalıklara yakalanan, çocuğunu kaybeden vb. içeriklerle sunulduğu görülmektedir.

- Haberlerde kullanılan görsel imge ve fotoğraflar incelendiğinde mağduriyet haberlerinde kadını ağlarken, elini başına koymuş vaziyette, çaresizlik içerisinde gösteren karelerin, cinsellik, fiziksel özellik vb. durumları ön plana çıkaran haberlerde ise kadının bedenini, dekoltesini, cinselliğini ön plana çıaran karelerin tercih edildiği görülmektedir.

- Kullanılan dil incelendiğinde, dilin de aynı şekilde cinsiyetçi söylemin devamlılığına hizmet ettiği görülmektedir. Bilim adamı, iş adamı, siyaset adamı vb. kullanımların sık olmasa da yer aldığı 
görülmektedir. Bu tür kullanımlar dilin ideolojik bir nitelik taşıdığını ve eril bakış açısıyla inşa edildiğini göstermektedir.

- Haberlerde hiçbir şekilde kadının iş hayatı, başarıları, zekası, performansı ön plana çıkarılmamış, kadını yüceltici sıfatlar kullanılmamıştır. Kadın dolaylı olarak biriyle ilişkilendirilerek yer almış ya da suçlu mağdur, bağımlı, korunması gereken, yapıda yansitılmıştır.

- Kadını ya da kadınlığı olumlayan ifadelerin eksikliğine ek olarak, erkeğin konumlandırılışı da korumacı bir anlayışla gerçekleşmektedir. Kadına karşı işlenen taciz, tecavüz, şiddet ve cinayet $\mathrm{vb}$. haberlere ait metinlerde suçlunun cinsiyetine hiç atıfta bulunulmamış; hepsinde de "erkek" olarak değil "kişi" olarak ifade edilmişlerdir.

Elde edilen veriler doğrultusunda bir değerlendirme yapıldığında geleneksel medya ve yeni medyanın kadına yaklaşımı, kadının temsili ve toplumsal alandaki varlığına dair bakış açısında bir farklılık olmadığı görülmektedir. Toplumsal değerler ve kültürel kodlarla şekillenen kadının zayıf, kırılgan, erkeğe bağımlı, toplumsal cinsiyet kalıpları içerisine belirlenmiş fonksiyonları (doğurmak, yemek yapmak, anne olmak, evi evirip çevirmek, cinselliğiyle erkeğe hizmet etmek vb.) olan ve bu kalıplara hapsedilmiş olma söyleminin yeni medya tarafından da meşrulaştırıldığ görülmektedir.

Sonuç olarak geleneksel medya ve yeni medyada kadının temsil biçimi ve kadına yaklaşım açısından yapılan araştırma konusu bağlamında belirgin bir farklılık görülmediği, kadının temsili açısından her iki mecrada da aynı şekilde erkek egemen eril bakış açısının ürettiği ve toplumsal yapı içerisinde meşrulaştırılan ikinci derecedeki konumunun sürekli yeniden üretilerek bunun devamlılığının sağlandığı görülmektedir. Varılan sonuçta geleneksel medya ve yeni medya arasında kadının temsili bağlamında dil, söylem ve bakış açısına dair bir farklılık olmadığı saptanmıştır. Yeni medya mecra olarak geleneksel medyadan farklılık gösterse de içerik olarak kadına bakış açısı, cinsiyetçi söylemin meşrulaştırılması noktalarında geleneksel medyayla örtüşmektedir. Yeni medya mecra olarak yeni olsa da kadın temsili ve kadına yaklaşım açısından geleneksel medya ile birebir örtüşmektedir.

\section{Kaynakça}

AITCHINSON, \& LEWIS, D. M. (2003). New Media Language, New York: Routledge. 
Sosyal Bilimler Dergisi 325

ALANKUŞ, S. İnal, A. (2000). “Güldürü Programlarında Kadının Temsili ve Kadına Yönelik Şiddet” Dünya Kitle İletişimi Vakfı Yayınları, Ankara.

BAYHAN, V. (2013). "Beden Sosyolojisi ve Toplumsal Cinsiyet", Doğu Batı Düşünce Dergisi (Toplumsal Cinsiyet), Sayı: 63, Ankara: Doğu Batı Yayınları.

BINARK, M. (2007). Yeni Medya Çalışmaları, der., Mutlu Binark Ankara: Dipnot Yayınları.

GREEN, L. (2010) The Internet - An Introduction To New Media, New York: Berg Publishers.

http://www.alexa.com/siteinfo/hurriyet.com.tr

http://www.hurriyet.com.tr

http://www.medyahukuku.org/makale/medya-nedir

İMANÇER, D. (2006). Medya ve Kadın, Ankara: Ebabil Yayıncılık.

KARS, N. (2013). Haberin Tarihi, Kuramları, Söylemi ve Radyo-Televizyon Haberciliği, İstanbul: Derin Yayınları.

KENDALL, S.\& TANNEN, D.(2001). Discourse and Gender, The Handbook of Discourse Analysis, Edited by Deborah Schiffrin, Deborah Tannen and Heidi E. Hamilton, Massachusetts: Blackwell Publishers.

LAUGHEY, D. (2002). Medya Çalışmaları - Teoriler ve Yaklaşımlar, Çev. Ali Toprak, Kalkedon Yayınları, İstanbul.

PACHECO, S; HURTADO, A. (2002). Media Stereotypes, Encyclopedia of Woman and Gender, Academic Press: California.

TANRIÖVER H.U. (2007). Medyada Kadınların Temsil Biçimleri ve Kadın Hakları İhlalleri, S. Alankuş (Derl.), Kadın Odaklı Habercilik İçinde, IPS İletişim Vakfı yayınları, İstanbul.

TOKGÖZ, O. (2013). Temel Gazetecilik, Ankara: İmge Kitabevi

ULUÇ, G. (2003). Küreselleşen Medya: İktidar ve Mücadele Alanı, İstanbul: Anahtar yayıncilık.

VAN DIJK, T. (1988). News As Discourse, New Jersey: Lawrence Erlbaum Associates.

VAN DIJK, T. (2003). Söylem ve İdeoloji: Çok Amaçlı Bir Yaklaşım, Söylem ve İdeoloji: Mitoloji, Din, İdeoloji, İstanbul: Su Yayınları

VAN ZOONEN, L. (1996). "Feminist Perspectives on The Media", Mess Media and Society, der., James Curran ve Michael Gurevitch. London: Arnold.

WOOD, J.T. (2009). Gendered Lives - Communication, Gender, and Culture, Boston: Wadsworth Cengage Learning. 
Z. AKMEŞE, K. DENIZ 326 